\author{
凟 料 \\ 〈日本茶業技術協会技術賞受賞研究〉 \\ チャ遺伝資源の超低温保存 \\ 静岡県茶業試験場 \\ 倉貫幸一 \\ (平成 6 年 12 月 7 日受理)
}

\title{
Cryopresevation of Genetic Germplasms in Tea Plants
}

\author{
Yukikazu KURANUKI \\ Shizuoka Tea Expreiment Station
}

チャの品種育成を効率的に進めるために, 育種素材となる遺伝資源を多く保有している ことは大変重要なことである。

現在, 自然環境は色々な面で破壊され，植 物の貴重な遺伝資源は品失の浮さ目に曝され ている。チャにおいても同様であり, 在来園 の放棄・改植, 他の使用目的のために壊され, 遺伝資源は滅少の一途である。しかし, 現在 のチャ遺伝資源の保存は围場で行われてお り，大量の遺伝資源を保存するためには固場 規模と多くの手間を必要とする一方, 病害や 寒害による喪失と実生泥入の危険性をはらん でいる。

イネ，ムギ等1)の多くの一年生作物では液 体窒素を用いた長期保存方法が確立し, 実際 に保存がなされている。アブラヤシ,ココナッ ツ等の熱帯性の大きな種子でも胚軸を摘出し て保存する方法 ${ }^{2,3,4}$ が確立されている。栄養 繁殖作物でも器官を用いた保存方法 ${ }^{5}$ が確立 されている。

チャの遺伝資源の保存について, 種子を $1^{\circ} \mathrm{C} て ゙$ 密封貯蔵すれば 6 年間発芽力を維持で

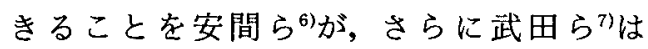
$-80^{\circ} \mathrm{C} て ゙ 2$ 日間保存できることを報告してい るが，液体窒素を用いた超低温保存について は報告されてない。

ここでは種子と培着茎頂の超低温保存につ いて紹介します。

\section{1. 種子の保存}

(1)完全な種子8,9)

チャ種子の最低生存温度は表 1 に示す通り $-7.5^{\circ} \mathrm{C} て ゙$, 処理温度が低くなるにつれて細菌 の活染が激しくなった。種子の水分含量と発

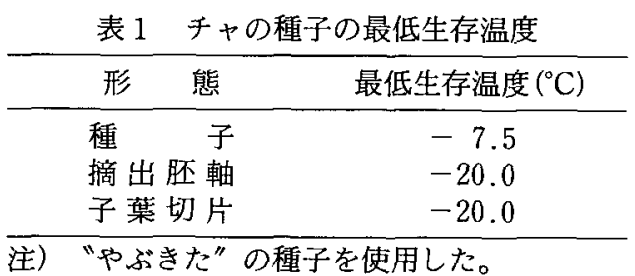
処理は $-3^{\circ} \mathrm{Cで}$ 涷結・植水後 12 時間以上放置し、 $-5 、-7.5 、-10 、-12.5 、-15 、-20$ と $-25^{\circ} \mathrm{C} て ゙$ 段階的に各温度で 1 日間凍結し、そ れぞれの温度で取り出した。

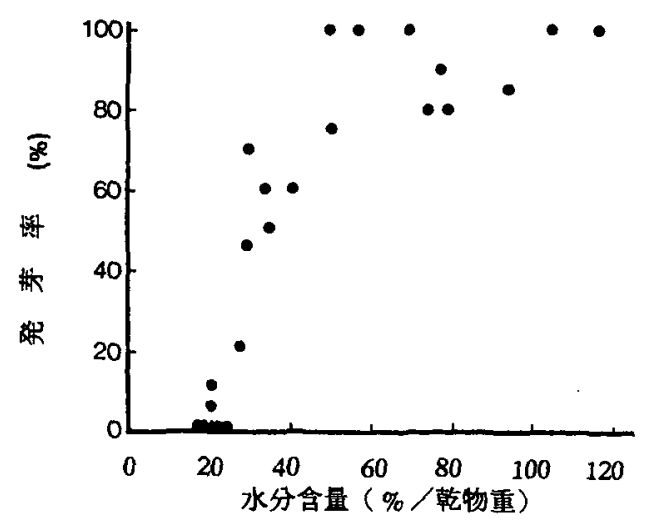

図 1 種子の水分含量と発芽との関係 
芽率の関係は図 1 に示す通りであった。新鮮 な種子から水分含量を乾物重当たりで $50 \%$ まで隇少させても発芽率の低下は見られな かったが，水分含量が $50 \%$ 以下になると発芽 率は急激に低下し，20\%以下になると生存は 確認できなかった。

示差熱分析 (冷却過程中の相変化一ここで は水の凍結一を調べる) の結果は図 2 に示す 通りであった。示差熱温度は新鮮な種子で約 $-8^{\circ} \mathrm{C}$, 水行含量 $50 \%$ までは- $12^{\circ} \mathrm{C}$ 以上と大き な差はなかったが, 水分含量が $30 \%$ 以下にな ると急激に低下し，20\%で約 $-23^{\circ} \mathrm{C}$ ， それ以 下の水分含量では出現しなかった。

一般に recalcitrant seed は種子が大きく， 低温と乾燥に耐えられないことは chin ら ${ }^{10}$ により指摘されている。チャの種子は大きく, 低温と乾燥に弱いことから, recalcitrant seed と考えられ，そのままでの超低温保存は 困難であると推察された。

(2)種子から摘出した胚軸と子葉切片 ${ }^{8,9)}$

摘出胚軸と子葉切片の最低生存温度は表 1

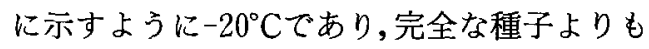

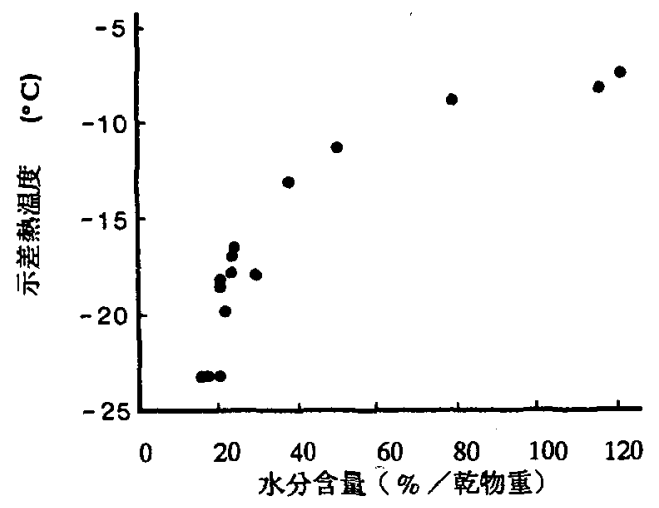

図 2 種子の水分含量と示差熱温度との関係

低温に耐えることができた。

ア) 摘出胚軸

摘出肧軸はシリカゲルを使い乾燥し，その 水分含量と生存との関係法図 3 の上に示す通 りである。肧軸の水分含量が $15 \%$ 以上の場合 の生存率はほほ $100 \%$ と高く, 水分含量が 15\%より滅少すると生存率が低下し, 水分含
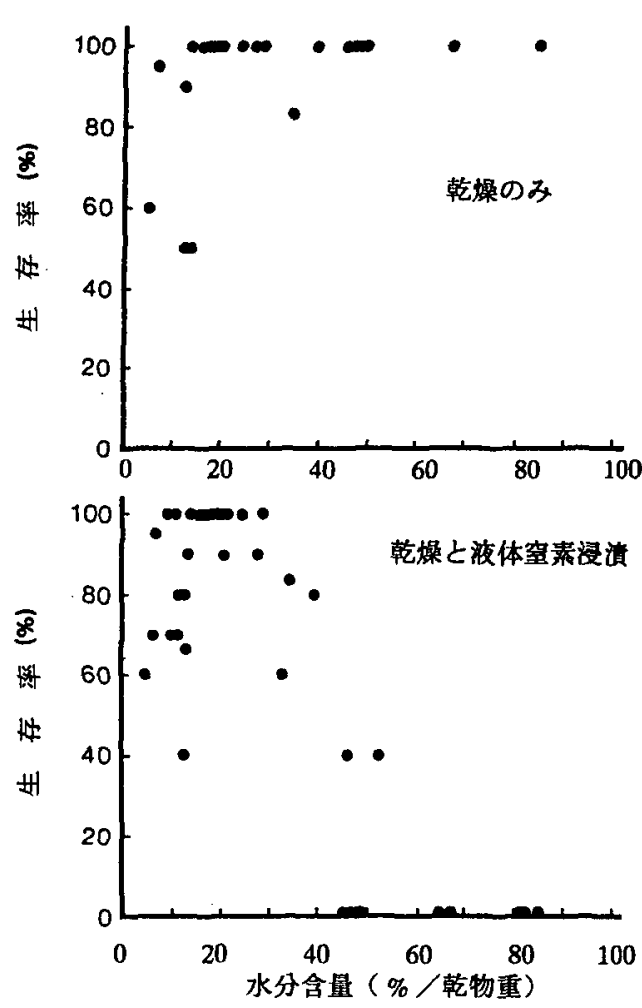

図 3 肧軸の水分含量と乾燥後からびに液体窒 素浸漬後の生存との関係

上図は乾燥のみの生存を、下図は乾燥 そして液体窒素に浸漬後の生存を示 于。

量 $5 \%$ で生存率は $50 \%$ になった。

各水分含量の胚軸における液体窒素処理後 の生存との関係は図 3 の下に示す通り, 胚軸 の水分含量が $60 \%$ 以上では生存するものが なく, 水分含量が $50 \%$ 以下で生存が確認さ れ，水分含量が $30 \sim 15 \%$ で汇 $100 \%$ の生存 を示した。さらに水分を減少させると生存率 が低下し, 水分含量が $5 \%$ で $60 \%$ の生存率を 示した。

摘出した胚軸は低温に強く, 乾燥にも強い ことが明らかとなり，さらに水分含量を 30〜 15\%に乾燥した胚軸は, 液体公素に浸漬 しても $100 \%$ 近く生存していたことから，液 体窒素中で超低温保存できることが明らかと なった。 


\section{イ）子葉切片}

子葉切片はシリカゲルを使い乾燥し, その 水分含量と生存との関係は図 4 の上に示す通 りである。水分含量が $30 \%$ 以上の子葉切片は $50 \%$ 以上の生存を示した。水分含量が $30 \%$ か ら少なくなるにつれて生存率が低下して $10 \%$ の水分含量で生存率は $0 \%$ になった。各 水分含量の子葉切片における液体窒素処理後 の生存との関係は図 4 の下に示す通り, 水分 含量約 30\%で生存が認められるけれども他 の水分含量では全く生存がなかった。液体窒 素処理前の各水分含量に対する子葉切片の生 存曲線は完全な種子と同様であることから, 種子が乾燥に弱い原因は大部分を占める子葉

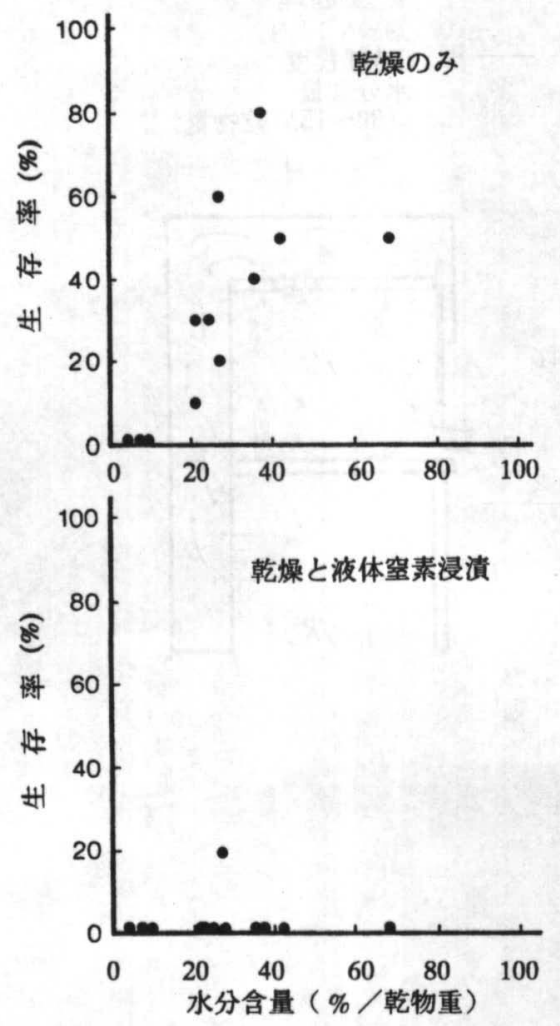

図 4 子葉切片の水分含量と乾燥後ならびに液 体窒素浸漬後の生存との関係

上図は乾燥のみの生存を、下図は乾燥 そして液体窒素に浸漬後の生存を示 す。
が乾燥に弱いことに起因している。

ウ) 肧軸の乾燥方法

シリカゲルを使い水分含量を調節する方法 は，多くの材料を扱う場合に不向きである。 そこでクリーンベンチ内で乾燥する時間を調 查した結果, 表 2 に示す通りである。乾燥時 間が 60 分以内では生存率が低く, しかも生育 が異常なものが多かった。9 90 分と 120 分の乾 燥で生存率は $100 \%$ で生育が正常であった

(写真 1) ことから, 胚軸の乾燥はクリーン ベンチ内で 120 分程度が適していた。

(3)胚軸の回復培養 ${ }^{11)}$

胚軸は $2 \mathrm{~mm}$ 程度と小さく, 生育させるため には無菌的に培養しなければならない。液体

表 2 胚軸のクリーンベンチ内での乾燥時間と 液体窒素処理後の生存

\begin{tabular}{lccccc}
\hline \multirow{2}{*}{ 項 目 } & \multicolumn{5}{c}{ クリーンベンチ内(分) } \\
\cline { 2 - 6 } & 30 & 45 & 60 & 90 & 120 \\
\hline 水分含量(\%) & 52 & 46 & 33 & 20 & 18 \\
生 存(\%) & 40 & 70 & 80 & 100 & 100 \\
正 常(\%) & & 20 & 40 & 100 & 100 \\
異 常(\%) & 40 & 50 & 40 & & \\
\hline
\end{tabular}

注）水分含量は乾物重当たりで示した。

正常は摘出胚軸が正常に生育し、異常は胚軸 のカルス化と芽や根が生育しないことであ る。

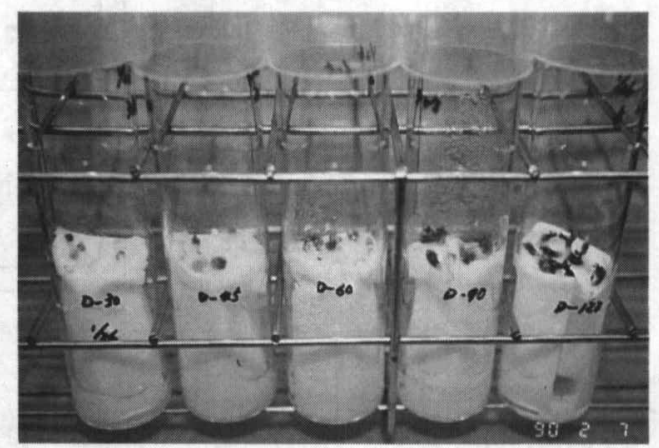

写真 1 胚軸の乾燥・超低温保存後の植物体の回復 乾燥はクリーンベンチ内で行い、 D-30、D-45、D-60、D-90、D-120は それぞれ、30分、45分、60分、90分間行っ た。 


\section{チャ遺伝資源の超低温保存}

窒素中で超低温保存した肧軸から植物体に回 復させる胚軸培養の培地は，1/2 MS を基本 として IBA $0.01 \mathrm{mg} / \ell, \mathrm{BA} 1.0 \mathrm{mg} / \ell$ の組合 せが最適であった。

(4)種子の採取時期 ${ }^{11}$

9 月上旬〜 10 月下旬に採取した種子を 12 月中旬に胚軸を摘出し, 乾燥処理とさらに液 体窒素浸漬処理をしたものの生存率は表 3 に 示す通りである。その結果 10 月中旬と下旬の 種子が充実した時期に採取したものから摘出 した胚軸の生存率が高く，しかも生育が健全 であった。

(5)種子から摘出した胚軸の超低温保存の手順
表 3 各時期の採取種子から12月14日に摘出し た胚軸の生存率 (\%)

\begin{tabular}{rccc}
\hline $\begin{array}{c}\text { 採種日 } \\
\text { 日 }\end{array}$ & $\begin{array}{c}\text { 摘出時 } \\
\text { の生存 }\end{array}$ & $\begin{array}{c}\text { 乾燥処理 } \\
\text { のみ }\end{array}$ & $\begin{array}{c}\text { 液体窒素 } \\
\text { 処理 }\end{array}$ \\
\hline 9.4 & 3 & & \\
9.13 & 15 & & \\
9.25 & 100 & 40 & 5 \\
10.2 & 100 & 15 & 25 \\
10.14 & 100 & $100^{*}$ & $95^{*}$ \\
10.22 & 100 & $100^{*}$ & $100^{*}$ \\
\hline
\end{tabular}

注）*は健全な生育を示した。 調查は 2 週間後に行った。

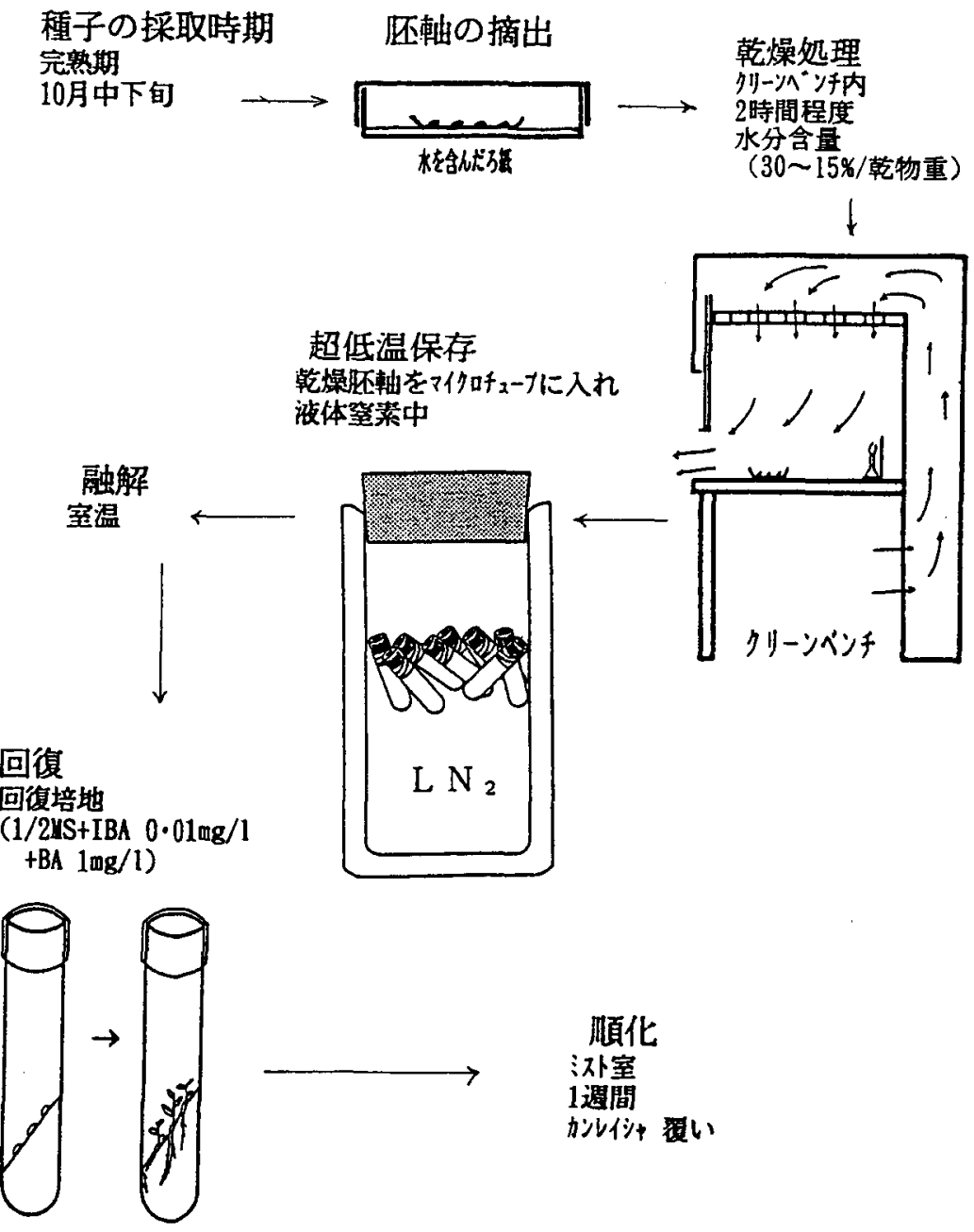

図 5 胚軸の超低温保存の手順 
（茶研報 $80 ： 43 \sim 50 ， 1994 ）$

は図 5 に示す通りである。

\section{2. 培養宔頂の保存}

(1)培養系への材料の導入と增殖 ${ }^{2,13,14)}$

茎頂の超低温保存は各々の操作を無菌的に 行うので，野外の材料を培養系に導入しなけ ればならない。

野外から培養系への導入には茥頂培養があ る。茎頂培養培地は， $1 / 2 \mathrm{MS}$ を基本として IBA $0.01 \mathrm{mg} / \ell$, BA $1.0 \mathrm{mg} / \ell$ と $\mathrm{GA}_{3} 1.0$ $\mathrm{mg} / \ell$ の組合せが最適であった。

無菌的な材料の増殖を行うために, MS を 基本培地として IBA $0.01 \mathrm{mg} / \ell$, BA 1.0 $\mathrm{mg} / \ell, \mathrm{GA}_{3} 10.0 \mathrm{mg} / \ell$ の組合せが最適で 2 か月で 7 倍の増殖を示した。

(2)低温順化 ${ }^{15}$

超低温保存のためには供試する材料の耐凍 性を高めることが大切である。増殖培地で増 殖した材料を $1 / 2 \mathrm{MS}$ のホルモンフリー培地 で約 2 か月間培養して, $10^{\circ} \mathrm{Cまたは} 20^{\circ} \mathrm{C}$ の 8 時間照明 $/ 5{ }^{\circ} \mathrm{C}$ の 16 時間暗黒の条件下で低 温順化を行った。低温順化期間と超低温保存 後の生存率, 植物体再生率との関係は図 6 に 示す通りである。生存率は 5 週間後から急激 に上昇し，植物体再生率は 8 週間後に最大と なった。この結果から,低温順化期間は $5 \sim 8$ 週間が適していた。

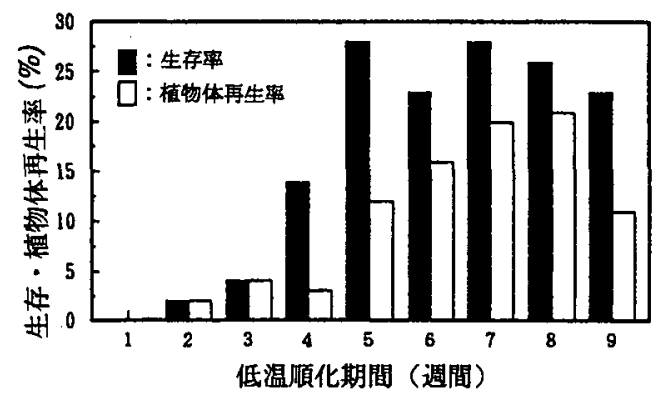

図 6 低温順化期間と超低温保存後の荎頂の生 存との関係

$10^{\circ} \mathrm{C} 8$ 時間照明 $/ 5^{\circ} \mathrm{C} 16$ 時間暗黑の条 件で順化を行った。

PVS 2 処理は $0{ }^{\circ} \mathrm{C} 20$ 分間である。夜体窒 素浸漬時間は 1 時間以上である。
(3)ガラス化法 ${ }^{16,17)}$

ア）前培養 ( $5^{\circ} \mathrm{C}$ 暗黒下)

低温順化した培養植物から荎頂を摘出し, PVS 処理の前に行う培養培地のショ糖濃度 と生存との関係を見たものが図 7 である。植 物体再生率は $0.2 \mathrm{M}$ で高かった。

前培責期間と植物体再生率との関係は図 8 に示す通りである。生存率，植物体再生率は

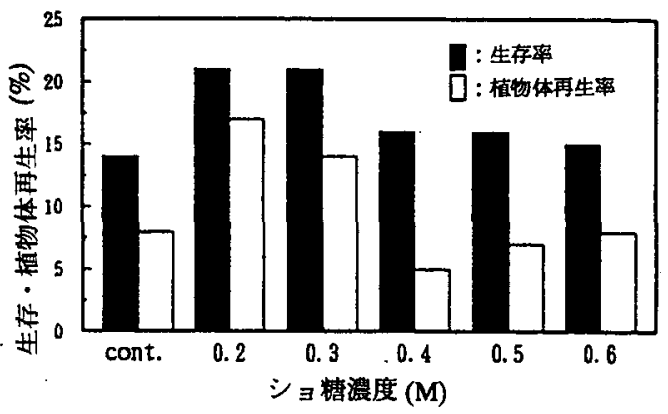

図 7 前培養培地のショ糖濃度と波体空素浸漬 後の茎頂の生存との関係

$10^{\circ} \mathrm{C} 8$ 時間照明 $/ 5^{\circ} \mathrm{C} 16$ 時間暗黑の条 件で順化を行った。 前培養期間は 1 日である。 PVS 2 処理は $0^{\circ} \mathrm{C} 20$ 分間である液体 窒素浸漬時間は 1 時間以上である。

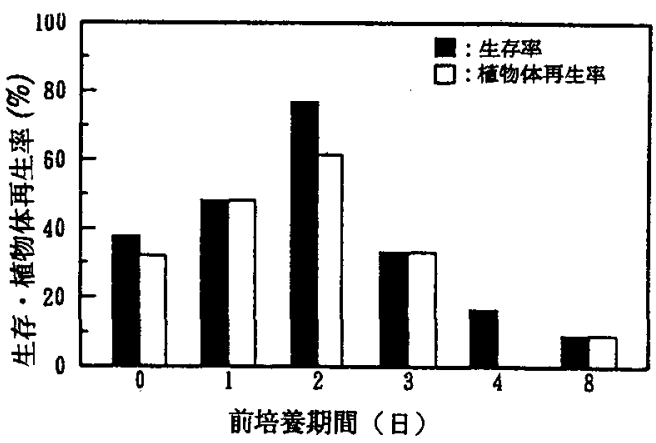

図 8 前培養期間と液体窒素浸漬後の茎頂の生 存との関係

$20^{\circ} \mathrm{C} 8$ 時間照明 $/ 5^{\circ} \mathrm{C} 16$ 時間暗黑の条 件で順化を行った。

PVS 2 処理は $0{ }^{\circ} \mathrm{C} 20$ 分間である。液体窒 素浸漬時間は 1 時間以上である。 前培養地は $0.2 \mathrm{M} シ ョ$ 糖+1/2MSであ る。 
チャ遺伝資源の超低温保存

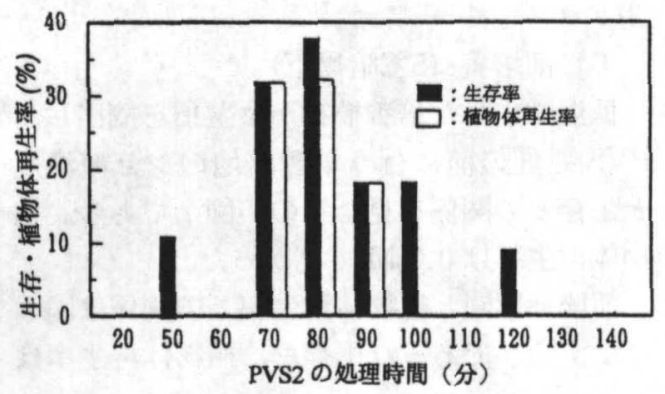

図 9 PVSの処理時間と液体窒素浸漬後の茎 頂の生存との関係

$20^{\circ} \mathrm{C} 8$ 時間照明 $/ 5^{\circ} \mathrm{C} 16$ 時間暗黒の条

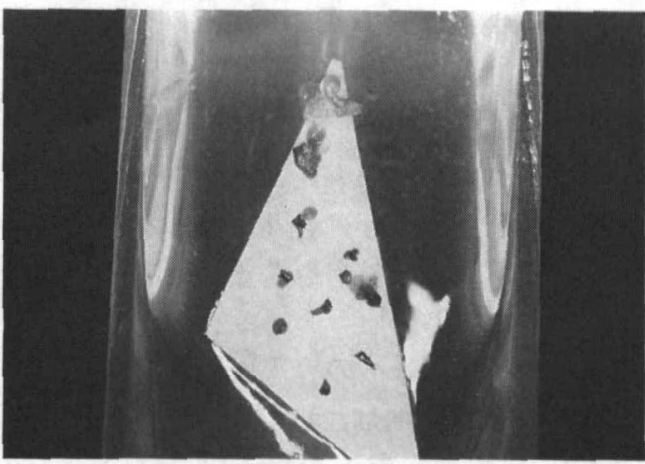

写真 2 ガラス化法による茎頂の超低温保存後 の植物体の回復（処理後 2 力月）

件で順化を行った。

前培養期間は 1 日である。

液体窒素浸漬時間は 1 時間以上であ る。

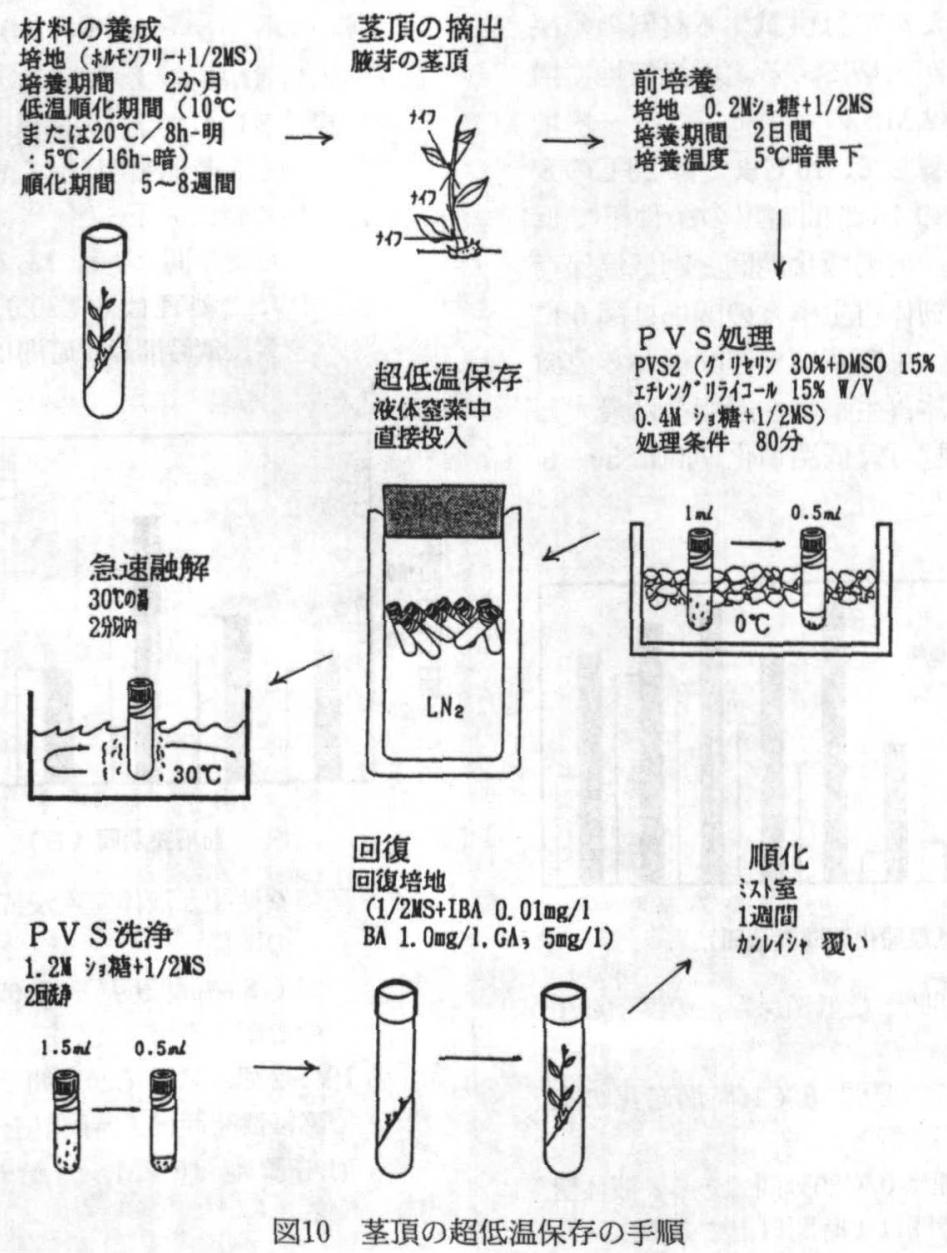


前培養 2 日間でそれぞれ $80 \%, 60 \%$ と最高と なった。

イ）PVS 2 の処理条件

PVS2(グリセリン $30 \% \mathrm{~W} / \mathrm{V}+\mathrm{DMSO} 15 \%$ $\mathrm{W} / \mathrm{V}+$ エチレングライコール $15 \% \mathrm{~W} / \mathrm{V}+0.4$ $\mathrm{M} シ ョ$ 糖 $+1 / 2 \mathrm{MS})$ の処理温度は $20^{\circ} \mathrm{C} よ り$ $0^{\circ} \mathrm{Cが}$ 適していた。処理時間と植物体再生率と の関係は図 9 に示す通りである。植物体再生 率は 70 と 80 分間で $30 \%$ 以上と高かった。

ウ）液体空素浸漬, 融解と回復処理

PVS 2 処理後, 茎頂をクリオチューブに入 れ直接液体窒素中で 1 時間以上浸漬した。融 解は $30^{\circ} \mathrm{C}$ 湯で急速に行い, $1.2 \mathrm{M}$ ショ糖十 $1 / 2 \mathrm{MS}$ の液体培地で 10 分間洗浄して茎頂 培養培地 ${ }^{12)}$ に植え付け植物体の回復を図った (写真 2 )。

エ）ガラス化法による茥頂の超低温保存の 手順は図 10 に示す通りである。

\section{3. 今後の問題}

超低温保存は多くの遺伝資源を永久的に保 存できる技術であるが, 再生個体に変異がで ないことと生存率が高いことが望ましい。

完熟した種子から摘出した肧軸は乾燥後の 水分含量を 30〜 15\%に調整すれば，100\%近 い生存率を示し, 生育も健全であった。しか し, 変異の可能性の有無については遺伝的に 同一な不定胚を誘導して超低温保存前後にお ける変異発生調査をする必要がある。さらに, 在来茶樹を対象として種子を利用して遺伝資 源の保存のために，1地域当たりの保存個体 数をどれくらいの規模すればよいのか明らか にする必要がある。

現在, ガラス化法による茎頂の超低温保存 での植物体再生率は $60 \%$ 程度であるが, 今後 植物再生率を向上させるために，アルギン酸 ビーズ乾燥法の利用やまったく新しい手法を 開発する必要がある。

\section{引用 文 献}

1) Stanwood, P. C. (1985): Cryopreservation of seed germplasm for genetic conservation. In Cryoperservation of Plant
Cells and Organs, K. K. Kartha, ed, CRC press, Inc. Boca Raton, Florida. ppl99 $\sim 226$.

$2)$ Grout, B. W. W., K. Shelton and H. W. Pritchard (1984), Orthodox behaviour of oil palm seed and cryopreservation of the excised embryo for genetic conservation, Ann. of Botany, 52, 381 384 .

3 ) Chin, H. F., B. Krishnapillay and Y. L. Hor(1989): A note on the cryopreservation of embryos from young coconuts (Cocos nucifera var. MAWA), Pertanika, 12,183 186 .

4) Chin, H. F., B. Krishnapillay and Z. C. Alang (1988): Cryopreservation of Veit chia and Howea palm embryos, Cryoletters, 9, 372 379 .

5) Sakai, A. (1985): Cryopreservation of shoot-tips of fruit trees and hervaceous plants. In Cryoperservation of Plant Cells and Organs, K. K. Kartha, ed. CRC press, Inc. Boca Raton, Florida. pp135 $\sim 158$.

6 ）安間 舜・渡邊 明(1958)：チャの有用 生殖質の長期保存, 茶試研報, $19,29 \sim 57$.

7 ) 武田善行 - 武弓利雄 - 池田奈実子 - 安間 舜 (1990)：チャ生殖質の長期保存一種子と 花粉一, 茶研報, $71,29 \sim 35$.

8 ) Kuranuki, Y. and S. Yoshida (1990): Freeze preservation of tea seeds anthe excised embryos in liquid nitrogen after desiccation. Proc. of the Annual Meeting and 30th Symposium Japanese Society of Plant Physiologists Tokyo, p71.

9) Kuranuki, Y. and S. Yoshida (1991): Cryopreserva tion of tea seeds and the excised embryogenic axes in liquid nitrogen, Proceedings of the International Symposium on Tea Science (1991,Shizuoka), pp419 422.

10) Chin, H. F., Y. L. Hor and M. B. Mohdlassim (1984): Indentification of recalcitrant 
seeds. Seed Sci \& Technol, 12, 429 $\sim 436$.

11）倉貫幸一(1992)：チャ胚軸培養に抢ける 採取時期, 摘出胚軸の乾燥並びに植物生長 調節物質の効果，茶研報， $76 ， 1 \sim 5$.

12）倉貫幸一・柴田真里子(1992）：チャの茎 頂培養における植物生長調節物質の濃度の 違いが生育に及ほす影響, 静岡茶試研報, $16,1 \sim 6$.

13）柴田真里子・倉貫幸一（1993）：チャの試 験管内挿木に抢ける培養条件の改良(1)M S 培地の基本成分の希釉度ならびにW P培地 との比較, 茶研報, $77,39 \sim 45$.

14）倉貫幸一・柴田真里子(1993)：チャの試 験管内挿木における培養条件の改良(2)植物
生長調節物質の最適条件の検討, 茶研報, $77,47 \sim 55$.

15）倉貫幸一・酒井 昭(1992)：培養チャ芽 の低温順化期間が $\mathrm{LM}_{2}$ 処理後の生存に及 ほす影響, 育雑, 42, 別册 1, 330 331.

16）倉貫幸一・酒井 昭(1991)：Vitrification（ガラス化）法による培養チャ芽の凍結 保存, 育雑, 別冊 2, 184 185.

17) Kuranuki, Y. and A. Sakai (1994): Cryopreservation of in vitro-grown shoot tips of tea(Camellia sinensis) by vitrification, 31st Annual Meeting Program and Abstracts Kyoto, Society for Cryobiology, p87. 